\title{
Amino acid requirements and amino acid supply in the sheep
}

By D. G. Armstrong, Department of Agricultural Biochemistry, University of Newcastle upon Tyne and E. F. AnNison, Unilever Research Laboratory, Colworth House, Sharnbrook, Bedford

The special features of nitrogen metabolism in ruminants, which stem from the extensive breakdown and synthesis of dietary protein in the rumen (see Hungate, I966), imply the absence of a specific dietary requirement for essential amino acids. Nevertheless, there is considerable theoretical and practical interest in defining the amino acid requirements of ruminant tissues in animals of known nutritional and physiological status. Direct methods of measurement based on the growth or production response of animals to varying intakes of amino acids are clearly inapplicable, and it is necessary to use indirect procedures. The successful development of re-entrant fistulas has made it possible to measure the uptake of amino acids from the small intestine and to use the duodenal fistula to supplement amino acid supply. In this paper methods of measuring amino acid requirement in sheep based on the changes in plasma amino acid (PAA) concentration or oxidation in response to different levels of amino acid supply are discussed in relation to quantitative results of amino acid uptakes obtained using re-entrant intestinal fistulas.

Interest in relationships between PAA patterns and amino acid supply arose from observations that post-absorptive changes in PAA concentrations were qualitatively dependent upon the amino acid composition of the ingested protein (see Almquist, I956). Subsequent studies showed that a PAA reference pattern could be used to determine the first limiting amino acid for growth (Smith \& Scott, 1965; Dean \& Scott, 1966).

Several workers have shown that in non-ruminants a suboptimal dietary content of an essential amino acid results in a low plasma concentration, and that a dietary excess results in a high plasma level (Zimmerman \& Scott, I965; Mitchell, Becker, Jensen, Harmon \& Norton, r968; Keith, Christensen \& Owen, 1972). When increasing amounts of the first limiting amino acid were fed, the plasma concentration remained low until the amount required for maximum growth was exceeded, when a sharp and linear increase in concentration was observed. The point of intersection of the two lines obtained when amino acid intake was plotted against PAA concentration has been accepted as a measure of amino acid requirement under the over-all conditions of the experiment. Results of animal performance in the pig provide support for the validity of the procedure (Keith et al. 1972).

Wakeling, Lewis \& Annison (1970) applied the technique to the measurement of 
the methionine and threonine requirements of sheep. When the plasma concentration of the test amino acid was plotted against the sum of the amount infused into the duodenum (assumed to be fully absorbed) and the amount present in duodenal digesta (corrected for incomplete digestibility using the results of Coelho da Silva, Seeley, Thomson, Beever \& Armstrong, 1972), the relationships for methionine and threonine were best described by two lines whose points of intersection were assumed to represent a daily requirement. The observations of Wakeling et al. (1970) have been extended by R. Mitchell, D. Lewis \& E. F. Annison (unpublished observations using similar animals and an identical feeding regimen) and mean values for methionine and threonine requirements are shown in Table I. The same procedure has been used by Nimrick, Hatfield, Kaminski \& Owens (1970) with growing lambs given urea as the sole nitrogen source, but in these studies the amounts of amino acids entering the small intestine in digesta is not known (Table $\mathrm{r}$ ).

Table 1. Methionine and threonine requirements of sheep measured by the plasma amino acid $(P A A)$ and the ${ }^{14} \mathrm{CO}_{2}$ excretion procedures. Food intake and amino acid requirements are expressed as a function of metabolic body-weight $\left(\mathrm{kg}^{0.75}\right)$

\begin{tabular}{|c|c|c|c|c|}
\hline \multirow{2}{*}{$\begin{array}{c}\text { Food intake } \\
\left(\mathrm{g} / \mathrm{kg}^{0 * 75} \text { per } \mathrm{d}\right)\end{array}$} & & \multicolumn{2}{|c|}{$\begin{array}{l}\text { Amino acid requirement } \\
\left(\mathrm{mg} / \mathrm{kg}^{0.75} \text { per } \mathrm{d}\right)\end{array}$} & \multirow[b]{2}{*}{ Refcrence } \\
\hline & Technique & Methionine & Threonine & \\
\hline $4 \cdot 2$ & $\begin{array}{l}\mathrm{PAA} \\
{ }^{14} \mathrm{CO}_{2} \text { excretion }\end{array}$ & $\begin{array}{l}105-125 \\
120-130\end{array}$ & $\begin{array}{c}310-34^{\circ} \\
317^{*}\end{array}$ & $\begin{array}{l}\text { Wakeling et al. (1970) } \\
\text { Mitchell, Lewis \& Annison, } \\
\text { unpublished observations }\end{array}$ \\
\hline $\begin{array}{l}6 \cdot 3 \\
6 \cdot 0_{+}^{+}\end{array}$ & $\begin{array}{l}\text { PAA } \\
\text { PAA }\end{array}$ & $\begin{array}{r}63 \dagger \\
207 \dagger\end{array}$ & $63 \uparrow$ & $\begin{array}{l}\text { Nimrick et al. (1970) } \\
\text { Reis ef al. (1973) }\end{array}$ \\
\hline & & $\begin{array}{l}\text { stimate. } \\
\text { int infused o } \\
\text { aing body-w }\end{array}$ & ht $40 \mathrm{~kg}$. & \\
\hline
\end{tabular}

Reis, Tunks \& Downes (1973), in similar experiments with mature merino sheep, observed that when increasing amounts of methionine are infused into the abomasum, the relationship between plasma-methionine concentration and the amount of methionine infused is described by two straight lines which intersected at a point equivalent to the infusion of $3.3 \mathrm{~g} / \mathrm{d}$ methionine or $207 \mathrm{mg} / \mathrm{kg}^{0.75}$ per d, assuming a body weight of $40 \mathrm{~kg}$ (Table $\mathrm{r}$ ).

An alternative approach to the measurement of amino acid requirement is based on the use of ${ }^{14} \mathrm{C}$-labelled amino acids. If the extent of oxidation of essential amino acids is significantly increased when their supply exceeds tissue requirements, the pattern of release of ${ }^{14} \mathrm{CO}_{2}$ following the administration of a labelled amino acid to an animal receiving a known amino acid supply might provide an alternative procedure to the measurement of PAA responses. This procedure has been evaluated by R. Mitchell, D. Lewis \& E. F. Annison (unpublished observations) in the sheep used to measure methionine and threonine requirements from PAA responses. Increasing amounts of methionine or threonine were infused intra-duodenally as before, but after the establishment of constant PAA concentrations 'weightless' 
amounts of ${ }^{14} \mathrm{C}$-labelled L-methionine or L-threonine were infused at a constant rate for $5 \mathrm{~h}$. The total output of $\mathrm{CO}_{2}$ and ${ }^{14} \mathrm{CO}_{2}$ was measured as described earlier (Annison, Brown, Leng, Lindsay \& West, 1967). The infusion period proved to be too short for the establishment of constancy of ${ }^{14} \mathrm{CO}_{2}$ output, but the plot of specific radioactivity of ${ }^{14} \mathrm{CO}_{2}$ against time allowed the asymptotic value to be calculated (see Annison et al. 1967). The proportion of the infused radioactivity released as ${ }^{14} \mathrm{CO}_{2}$ during the infusion period was also calculated. When these values were plotted against the amounts of amino acid infused into the duodenum, in each case the relationships were described by two straight lines whose points of intersection were assumed to coincide with the amino acid requirement. The results obtained by the PAA response and ${ }^{14} \mathrm{CO}_{2}$ output procedures were in good agreement (Table $\mathrm{r}$ ).

The requirements for methionine and threonine given by Wakeling $e$ t al. (1970) have been compared with supplies of these amino acids to sheep, of average bodyweight $45 \mathrm{~kg}$ given each of seven diets and the results are shown in Table 2. Amino acid supply has been taken as the difference in daily amount flowing into and out of the small intestine, the daily flows of digesta measured having first been corrected to $100 \%$ recovery of the marker, chromic oxide. On the basis of a threonine requirement for a $45 \mathrm{~kg}$ sheep of $5.65 \mathrm{~g} / \mathrm{d}$, all but one of the diets would appear inadequate, while for a methionine requirement of $2.0 \mathrm{~g} / \mathrm{d}$, the same applies in four of the seven diets listed. In three of the diets threonine would appear to be a limiting amino acid and, in another, the grass-fed diet (Proud, 1973), methionine; in the remaining three diets both amino acids would appear limiting with little to choose between them as to which was likely to be the first limiting metabolite.

Before accepting such conclusions, however, it is necessary to stress that the requirements shown in Table $\mathrm{I}$ refer to a specific dietary situation, i.e. that pertaining under particular inflows to the tissues of energy, essential amino acids, other than those under test, and non-essential amino $\mathrm{N}$ which collectively will govern tissue protein deposition and wool growth. Furthermore, there is the added complication that, while methionine can fully meet the requirement for cyst(e)ine, the latter can spare the requirement for methionine to the extent that methionine is serving as a source for cyst(e)ine (Meister, 1965$)$. In the chick cyst(e)ine can contribute $60 \%$ of the total methionine requirement (see Agricultural Research Council, 1963) whereas in the pig, the comparable value is assumed to be $50 \%$ (see Agricultural Research Council, 1967). In the sheep, the value may be higher because of the high content of cystine in wool. Thus, in any consideration of a methionine requirement, we need to consider firstly the amounts of cyst(e)ine being absorbed daily, and secondly the extent to which the measured methionine requirement includes that used to provide the cyst(e)ine required.

As an alternative approach, an attempt has been made to calculate a requirement for individual essential amino acids assuming that the diets at the amounts of intake specified in Table 2 were fed to sheep of $45 \mathrm{~kg}$ body-weight. Such requirements (see Table 3) are clearly minimal in that it has been assumed that the absorbed amino acid is used without loss in meeting the demands for maintenance, tissue protein deposition and wool growth; also, requirements for specialized aspects of 


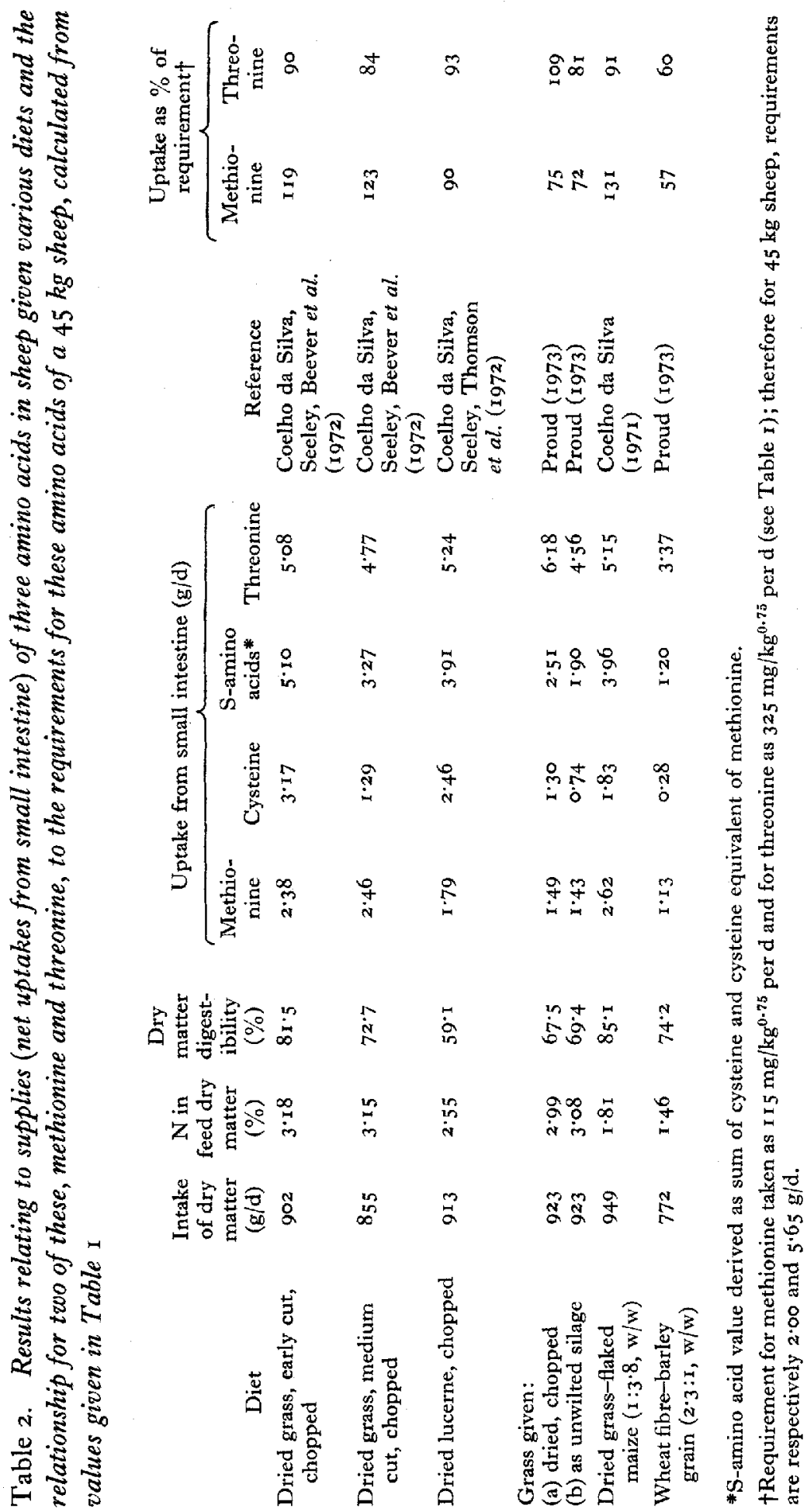




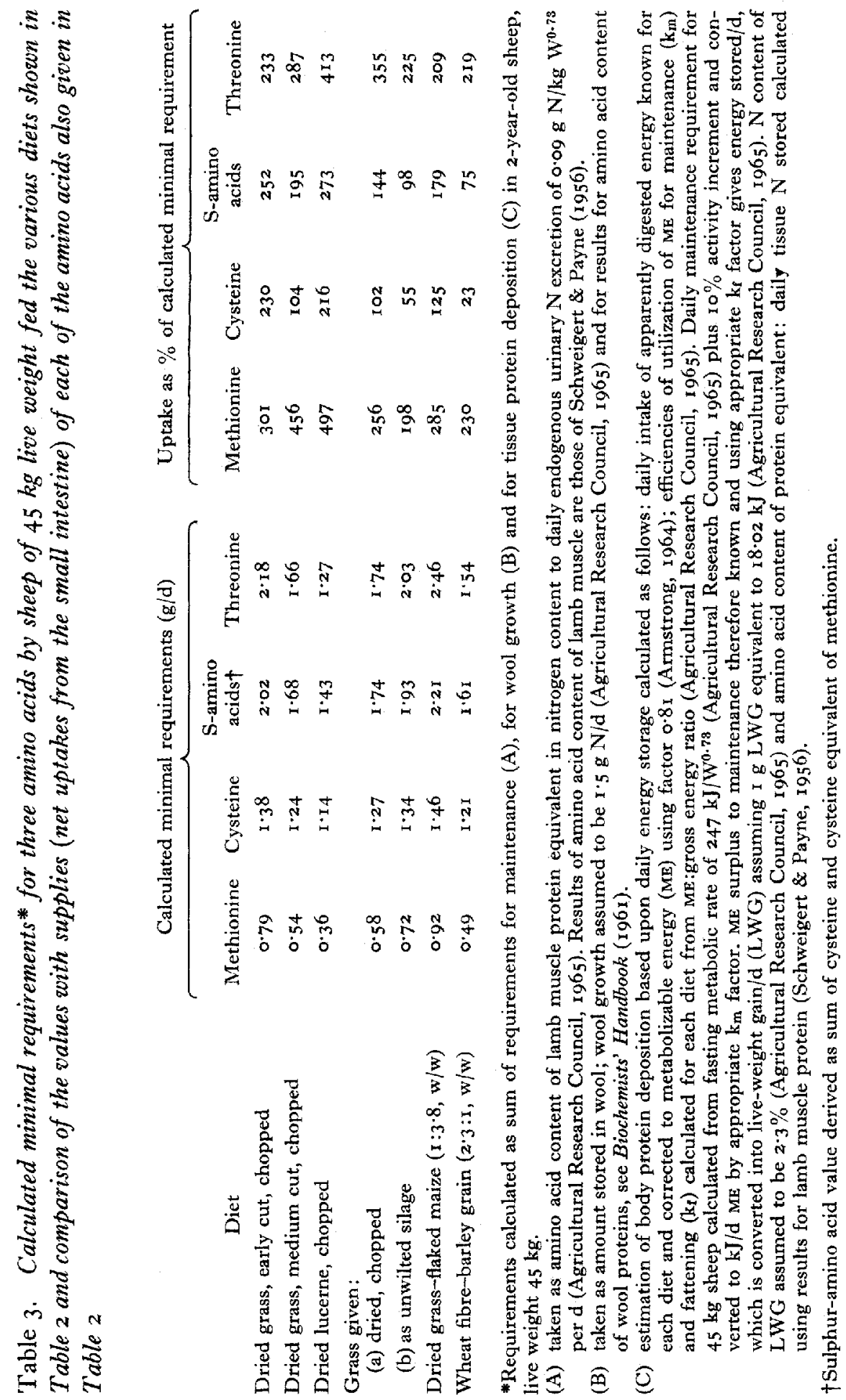


metabolism have been ignored. The method used in computing the requirements is outlined in the footnotes to Table 3. The theoretical $\mathrm{N}$ balances obtained from the calculations showed reasonable agreement with observed values; e.g. for the dried lucerne and unwilted silage diets the theoretical and actual $\mathrm{N}$ balances were respectively $2 \cdot 0$ and $2 \cdot 5 \mathrm{~g} \mathrm{~N} / \mathrm{d}$, and $4 \cdot 9$ and $4 \cdot 4 \mathrm{~g} \mathrm{~N} / \mathrm{d}$.

Neither threonine nor methionine were limiting in any instance. However, cysteine was barely adequate in one diet (grass fed as dried grass) and was inadequate in a further two, i.e. unwilted silage and the wheat fibre-barley diet. When, however, allowance is made for the surplus of methionine contributing irreversibly to the cysteine requirement by considering a total $\mathrm{S}$-amino acid requirement, the supply was adequate for the dried grass, borderline for the silage diet and inadequate for the wheat fibre-barley diet. The other essential amino acids and arginine were in surplus in all diets, but the one showing the least excess over requirement was arginine. In the young rat this amino acid cannot be synthesized at a rate commensurate with optimal growth; in the chick it is an essential amino acid (Meister, 1965). The situation regarding the growing ruminant is not known but is likely to be comparable to that for the rat.

The results presented in Table 3 provide support for the conclusions of various workers that either methionine or cyst(e)ine is the first limiting amino acid in the sheep. Thus, the infusion of L-cysteine or DL-methionine directly into the abomasum of sheep markedly increased wool growth (Reis \& Schinckel, I963; Reis, 1967). On the basis of PAA analyses methionine was considered as possibly the first limiting amino acid in lambs fed semi-purified diets (Schelling, Hinds \& Hatfield, 1967).

The findings presented in Table 3 suggest that with most dried forage diets the supply of S-containing amino acids to the host animal would be adequate for wool growth. This is not necessarily true for silage and Barry, Fennessy \& Duncan (1972) have shown that intake and wool growth of sheep given an untreated silage were markedly increased by the intra-peritoneal administration of methionine.

We must emphasize that the essential amino acid requirements discussed in this paper refer to specific dietary situations, and provide only a guide to dietary formulations. The procedures used to assess requirements are inevitably complex, but the results obtained should prove useful in providing a framework which facilitates the speedier indentification of the limiting amino acids for growth, or for milk or wool production. The animal response to protected amino acids (see Annison, 1972) may prove to be the most effective practical method of both identifying the first and subsequent limiting amino acids, and of meeting the amino acid requirements for optimal production.

\section{REFERENCES}

Agricultural Research Council (1963). The Nutrient Requirements of Farm Livestock. No. 1 Poultry. London: Agricultural Research Council.

Agricultural Research Council (1965). The Nutrient Requirements of Farm Livestock. No. 2 Ruminants. London: Agricultural Research Council.

Agricultural Research Council (1967). The Nutrient Requirements of Farm Livestock. No. 3 Pigs. London: Agricultural Research Council. 
Almquist, H. J. (1956). In Amino Acid Handbook p. 136 [R. J. Block and K. Weiss, editors]. Springfield, Ill.: C. C. Thomas.

Annison, E. F. (1972). In Nutrition Conference for Feed Manufacturers p. 2 [H. Swann and D. Lewis, editors]. Edinburgh and London: Churchill Livingstone.

Annison, E. F., Brown, R. E., Leng, R. A., Lindsay, D. B. \& West, C. E. (1967). Biochem. F. 104, г 35.

Armstrong, D. G. (1964). F. agric. Sci., Camb. 62, 399.

Barry, T. N., Fennessy, P. F. \& Duncan, S. J. (1972). Proc. N.Z. Soc. Anim. Prod. 32, 48.

Biochemists' Handbook (196I). p. 702 [C. Long, editor]. London: E. \& F. N. Spon Ltd.

Coelho da Silva, J. F. (I971). The digestion of nitrogenous constituents in forage and forage-cereal diets by adult sheep. PhD Thesis, University of Newcastle upon Tyne.

Coelho da Silva, J. F., Seeley, R. C., Beever, D. E., Prescott, J. H. D. \& Armstrong, D. G. (r972). Br. F. Nutr. 28, 357.

Coelho da Silva, J. F., Seeley, R. C., Thomson, D. J., Beever, D. E. \& Armstrong, D. G. (I972). Br. F. Nutr. 28, 43 .

Dean, W. F. \& Scott, H. M. (Ig66). F. Nutr. 88, 75.

Hungate, R. L. (т966). The Rumen and its Microbes. New York and London: Academic Press.

Keith, M. O., Christensen, D. A. \& Owen, B. D. (1972) Can. Y. Anim. Sci. 52, 163.

Meister, A. (1965). Biochemistry of the Amino Acids Vol. I. 2nd ed. New York and London: Academic Press.

Mitchell, J. R., Becker, D. E., Jensen, A. H., Harmon, B. G. \& Norton, H. W. (1968). I. Anim. Sci. 27, 1372 .

Nimrick, K., Hatfield, E. E., Kaminski, J. \& Owens, F. N. (1970). 7. Nutr. roo, rzor.

Proud, C. J. (1973). A study of the digestion of nitrogen in the adult sheep. PhD Thesis, University of Newcastle upon Tyne.

Reis, P. J. (I967). Aust. F. biol. Sci. 20, 80 9.

Reis, P. J. \& Schinckel, P. G. (1963). Aust. F. biol. Sci. 16, 218.

Reis, P. J., Tunks, D. A. \& Ilownes, A. M. (1973). Aust. F. biol. Sci. 26, 249.

Schelling, G. T., Hinds, F. C. \& Hatfield, F. E. (1967). F. Nutr. 92, 339.

Schweigert, B. S. \& Paync, B. J. (1956). Bull. Am. Meat Inst. Fdn. No. 3.

Smith, R. E. \& Scott, H. M. (1965). F. Nutr. 86, 45.

Wakeling, A. E., Lewis, D. \& Annison, E. F. (1970). Proc. Nutr. Soc. 29, 60A.

Zimmerman, R. A. \& Scott, H. M. (1965). F. Nutr. 87, I3. 